\title{
A proposition for an integrated church and community intervention to adolescent and youth sexual reproductive health challenges
}

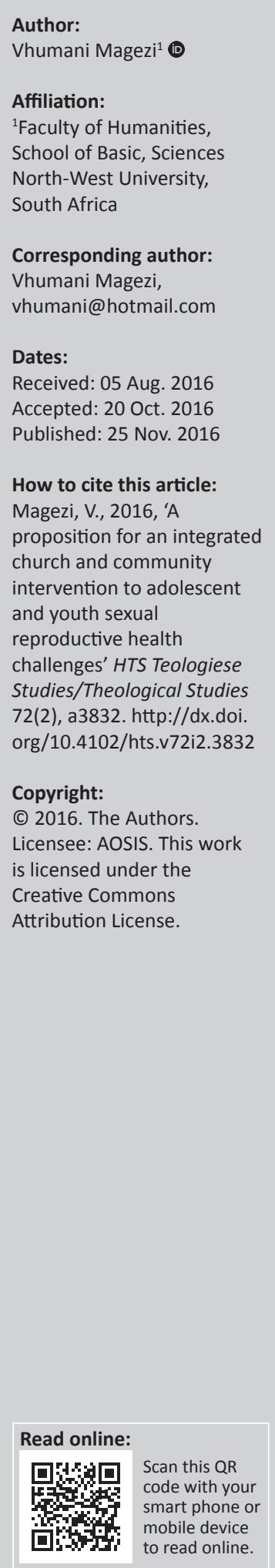

Adolescents and youth in South Africa comprise about $30 \%$ of the total population. This phenomenon is referred to as a youth bubble. Research shows that $52 \%$ of young people have had full penetrative sex by age 17 , and yet $35 \%$ of teenagers who have sex say they only sometimes wear a condom, while $32 \%$ who have sex say they never wear a condom. Furthermore, studies show that more than half $(52 \%)$ of parents of teenagers and youth are unaware of their children's sexual experiences. This situation is insignificantly different between the youth who frequently attend church and those who do not go to church. Responses by churches to the situation have ranged from denialism and hence only maintaining an abstinence stance to superficial youth sexuality discussions that only scratch on the surface. Data indicate that many adolescents seldom have an opportunity to discuss issues of sexual and reproductive health with a caring, knowledgeable adult and are often confronted with unresponsive health services. In response to the situation, there is growing awareness of the important role that religious communities play in adolescents and youth sexual health. The National Adolescent Sexual and Reproductive Health and Rights Framework Strategy (2014-2019) encourage parents and faith-based organisations to bridge this gap by empowering adolescents and youth regarding sexuality issues. The fourth priority of the strategy advocates for a strengthening and scaling up of community networks aimed at supporting adolescents. The churches, however, are caught in a dilemma where on the one hand they have to uphold (teaching) the biblical moral values of abstinence and at the same time respond to the realities of youth who are engaging in sex. With the church being a subsystem of society, a question that is posed is: how should a constructive engagement between church and society regarding youth sexual reproductive health be done? A practical theological response of the church to adolescents and youth sexual reproductive health (AYSRH) that is dialectic and juxtaposes the church and its distinctive values and at the same time practically responding to realities of the needs of adolescents and youth is proposed. In such a model, an engagement that upholds the sacredness of the church while observing the public role of the church as a community institution is advanced.

\section{Context and background}

About 30.2\% of South African population is younger than 15 years (SA Census 2011; Statistics South Africa 2015:1). Overall South Africa is made up young people. UNFPA (2016) drawing from national statistics reported that:

South Africa's population is largely made up of young people; those who are below the age of 35 years constitute about 77.6 per cent of the total population. With over 50 million South Africans, 18.5 per cent are between the ages 10-19; and 24 per cent are aged 15-24. (p. 1)

This phenomenon is referred to as a youth bubble or bulge. This youth bulge could result in demographic dividend, which Gribble and Bremner (2012:1) described as an accelerated economic growth that arises from changes in population demographics if the right investments are made by the country. HSRC (n.d.) advised that for South Africa to reap the demographic dividend the government should invest in youth health and other services such as education. Various society actors through multisectoral approaches should deliver these services. HSRC (n.d.) maintained that:

in order to reap dividend from our youth there is a need for a multi-sectoral approach which considers reproductive and sexual health issues as one aspect of personal development, with links to a range of other health and social services. (pp. 10-11)

The HSRC added that there is need to include innovative programmes that address adolescent health issues.

Note: This article is published in the section Practical Theology of the Society for Practical Theology in South Africa. 
Research reports and various policy documents that include the National Adolescent Sexual and Reproductive Health and Rights Framework Strategy (2014-2019), UNESCO (2013), UNFPA (2014), Lawler (2015), Frank et al. (2008), Lebese et al. (2013), Beksinska et al. (2014) and Malan (2014) present a disturbing national adolescent sexual reproductive health situation. They show that $52 \%$ of young people have had full penetrative sex by age 17 , and yet $35 \%$ of teenagers who have had sex say they only sometimes wear a condom, while $32 \%$ who have sex say they never wear a condom. More than half $(52 \%)$ of parents of teenagers and youth are unaware of their children's sexual experiences. More than 2300 girls between the ages of 15 and 24 contract HIV every week. Statistics for boys in this category are also equally high. Research shows that the incidence of new HIV infections among young females is more than four times higher than that of their male counterparts. 'With over 400000 new HIV infections a year, South Africa still ranks first in HIV incidence in the world' (Malan 2014:1). This situation is insignificantly different between the youth who frequently attend church and those who do not go to church particularly considering that $85.6 \%$ of South African's confess to be Christians (Statistics South Africa 2013:32).

Data indicate that many adolescents seldom have an opportunity to discuss issues of sexual and reproductive health with a caring, knowledgeable adult and are often confronted with unresponsive health services. This situation should indeed be of society and community concern. Magezi (2007:176, 2012:1) rightly maintained that a church is a subsystem of society. In response to this disturbing situation, Frank et al. (2008) observed that there is growing awareness of the important role that religious communities play in adolescents and youth sexual health. Frank et al. (2008) in their study, in which the findings were published under the title 'Risky sexual behaviours of high-school pupils in an era of HIV and AIDS', revealed that Christianity had a protective influence on pupils. These findings corroborate with findings in Zambia that revealed that religious affiliation resulted in delayed sexual initiation (Agha, Hutchinson \& Kusanthan 2006). The role of church communities in addressing community challenges such as adolescents' sexual reproduction is widely acknowledged. The National Adolescent Sexual and Reproductive Health and Rights Framework Strategy (2014-2019) fourth priority (pillar) advocates for a strengthening and scaling up of community networks aimed at supporting adolescents. The strategy encourages parents and faith-based organisations (FBOs) to participate in addressing adolescents' sexual reproductive health matters by empowering them on sexual issues. The church should do so, among other things, through bridging the church and society or community divide where churches are generally silent on youth and adolescents' sexual issues.

The churches, however, are caught in a dilemma where on the one hand they have to uphold the biblical moral teaching and values of abstinence and at the same time respond to the realities of youth who are engaging in sex. Frank et al.'s (2008) study noted that Christianity generally preaches abstention rather than condom use, which is an approach at odds with reality. This therefore results in adolescents and youth being exposed to increased risk of HIV infections once they become sexually active. A question that arises from this situation is: considering that the church is a subsystem of society and yet it is a separate structure, could there be a constructive engagement and integration of church and society in addressing adolescents and youth sexual reproductive health (AYSRH) issues? In response to this question, a practical theological response of the church to AYSRH that is dialectic and juxtaposes the church and its distinctive values and at the same time practically responding to realities of the needs of adolescents and youth is proposed. In such a model, an engagement that upholds the sacredness of the church while at the same time observing the public role of the church as a community institution is maintained.

\section{Church AYSRH ministry within public pastoral care - A nexus}

Practical theology, particularly pastoral care, by considering the churches' contribution to the public issue of AYSRH, is responding to the call of public pastoral care. A major shift that can be observed within pastoral care movement in recent years is a shift towards public theology. The University of Pretoria Centre for Public Theology (n.d.) explains that the role of public theology is to assist the church to be clear on its public responsibility and the best ways to fulfil it. Thus the shift of pastoral care to public theology is concerned with ensuring that pastoral care increasingly takes a public dimension. ${ }^{1}$ In the collection of essays published in Pastoral care and counseling: Redefining the paradigms edited by Ramsay (2004), she (Ramsay) noted the critical developments in pastoral care discipline of the growing interest in public theology as a significant trend. In agreement with Ramsay, Ashby (2004) charged pastoral care scholars to be more public in their scholarship. He argued that scholars should identify theological concepts and perspectives to help them understand how to bring public wholeness. Miller-McLemore's (2005) essay Pastoral theology and public theology describes the two critical developments regarding the current movement of pastoral care to public theology as: (1) the concern about the silence of mainstream Christianity on key social issues; and (2) awareness of the limitations of pastoral focus on the individual alone, hence the need to focus on whole persons and public issues. Flanagan and Thornton (2014:131) in The Bloomsbury guide to pastoral care rightly advised that public theology is an indispensable partner of pastoral care in contributing to public health dialogue in the form of congregational health and public practices of care. They (Flanagan and Thornton) added that the public nature of pastoral care is already evident in hospitals and schools; hence this needs to be strengthened (ibid).

1.The reference to public theology here is in the context of pastoral care discipline developments. However, for discussion focusing on Public Theology please see the developments. However, for discussion focusing on Public Theology please see the following publications: Forster (2015), Swart and D
Koopman (2009), Bezuidenhout and Naudé (2002). 
Strachan and Vanhoozer (2015:17) explained that public theology is about a ministry that is 'involved with people in and for the community'. A public theology ministerial dimension is particularly important because, as Strachan and Vanhoozer (2015:17) noted, it identifies the church as a witnessing community in the world that the pastor is called to participate. Such a ministry approach calls for and locates power in a congregation to live out the gospel in its context (Strachan \& Vanhoozer 2015:174-176). Juma (2015:2) maintained that public theology is like pastoral theology because it is contextual. It arises out of and is influenced by prevailing contemporary issues. Merging public and pastoral theology, Juma (2015:3) urged that this theological approach is concerned with how the Christian faith addresses matters in society at large. It is concerned with the 'public relevance' of Christian beliefs and doctrines. Theology is an ongoing contextual enterprise. Public theology therefore is about interpreting and living theological beliefs and values in the public realm (Juma 2015:3). If public theology is about living theological beliefs and values, therefore it is about life. This way, public theology intersects with pastoral care. Louw (2014) rightly stated that pastoral care is a life science. It is faith care that is life care (Louw 2014, 2008). Juma (2015:10) however admitted that living out one's theological convictions and beliefs, and providing care that is informed by the contextual realities, is both a challenge and an opportunity. The challenge is in seeking to maintain a helpful balance between one's personal convictions and those encountered in therapeutic relationships.

Viewing pastoral care as a public enterprise entails that pastoral care extrapolates its hope-giving and healing roles to the public. This task entails that pastoral care moves away from being a private individual affair to a public communal role (McClure 2010:1-4). This shift is about making Christians and congregations agents of hope and healing to the public square as rightly titled on the monograph on pastoral care pathways to the public square (Graham \& Rowlands 2005). Louw (2014:52), focusing on Christians' responsibility in instilling hope in people, advises that Christians should be agents of hope. Being agents of hope 'should be the focal point in a practical theological approach to the human quest for meaning and dignity' (Louw 2014:52). He (Louw) therefore concluded that pastoral care as soul care 'should be the realm of life and engagement with existential reality' (Louw 2014:52).

The need for practical theology, particularly pastoral care to be public, is high in the South African context of high adolescent and youth HIV incidence. Congregations as subsystems of communities should act as connecting points between church communities and the rest of society (Magezi 2012). It is hardly an exaggeration that the situation of AYSRH is desperate. Certainly, a situation where more than 2300 girls between the ages of 15 and 24 contract HIV every week and over 400000 new HIV infections are recorded among this 15-24 age group per year (Malan 2014:1), which puts South Africa as first in HIV incidence in the world, should be a huge concern to all South Africans. Equally, the situation of adolescents' pregnancy is alarming. For instance, it is estimated that there were over 30000 teenage pregnancies of school-going girls during the period 2010-2014 recorded in Eastern Cape. A baseline study by Restless Development supported by UNFPA in the same province revealed that there were over 70 pregnancies in just a year at one school (Restless Development 2015:4-6). The situation is indeed desperate.

Many HIV organisations and leading public personalities expressed despair regarding the deplorable situation of adolescent sexual reproductive health and high HIV rates at the recent 21 International AIDS Conference in Durban (18-22) by unanimously saying something must change. Philanthropists Bill Gates and Elton John, as well as the influential Executive Director of Section 21 Company, Mark Heyhood, took turns on Power FM radio station on 21 and 22 July 2016 to air their concerns. They all lamented the desperate situation of AYSRH as well as high HIV rate among adolescents and youth. In such a situation practical theology and particularly pastoral care should, as Louw (2014:52) advised, be the realm of life and engage with existential realities. This desperate issue of AYSRH deserves special focus and attention by churches as well.

\section{Consideration points for an AYSRH church and community constructive ministry}

It is widely acknowledged that churches play a critical role in community initiatives particularly in driving some HIV and health responses in many African countries. This role has been widely documented. Churches' contribution in health and HIV extends beyond psychological and spiritual care to practical interventions (Babbel 2012; Dambisya and Ichoku 2012; Foster 2010; Green et al. 2002; Magezi 2012; Samuels, Geibel and Perry 2010; Zvobgo 1986). The World Council of Churches (2010) reported that World Health Organisation estimates that FBOs particularly churches provide 30\% - 70\% of health care in the developing world. Mati (2013) further observed that FBOs (churches) are the most prominent manifestations of civil society in Africa. He added that FBOs (churches) have been playing a key role in African development and this situation will continue for many years to come. However, Mati (2013) laments the inadequate attention given to FBOs in social scientific analysis.

The challenge that churches experience is how to integrate church communities/assemblies or congregations with the rest of society. The 'how' does not necessarily refer to practical techniques but rather to a quest for a legitimate integration of church and society that is theologically sound and practically relevant. This concern is about churches or congregations' relationship with the rest of the community or society. Churches are subsystems of communities (Magezi 2007:146), and yet they are a distinct and separate community. The church is in the world but is not of the world (John 17:14-16). 
It is shaped by ethos and values that are different from the rest of the society and community. Churches are viewed as sacred spaces, and in many cases they are viewed as institutions that uphold high moral standards. As such there is need to maintain the churches' sacredness but at the same time ensuring that they remain social and community institutions that are informed and respond to the prevailing challenges such as AYSRH in our case. The place and role of the church should be clearly understood in order to ensure that it is meaningfully engaged in the practical realities of life but maintaining its distinct theological basis.

The churches or congregations' engagement in public issues entails three interlocking dimensions that inform their work as shown in Figure 1. These dimensions indicate the areas of church and community integration that should be observed and respected.

The first dimension concerns the distinctive role of churches or congregations. At popular level, communities recognise church communities (congregations) as religious institutions that are shaped and informed by their spiritual framework. Despite the fact that church people are people belonging to the same community, there is an understanding that they are separate and exclusive (Magezi 2007, 2012). Community leaders often refer to church members as church people or people belonging to churches. These people are accorded a separate status. This distinction is critical for clarity on the role and function of churches. It indicates its foundational basis, principles and values. For instance, while churches are encouraged to participate in youth sexual reproductive health issues, it should be noted that congregations are not public health institutions or centres. Secondly, congregations are not specially equipped in many cases to deal with sophisticated public health issues and discussions. Thirdly, congregations operate from a particular Christian value and

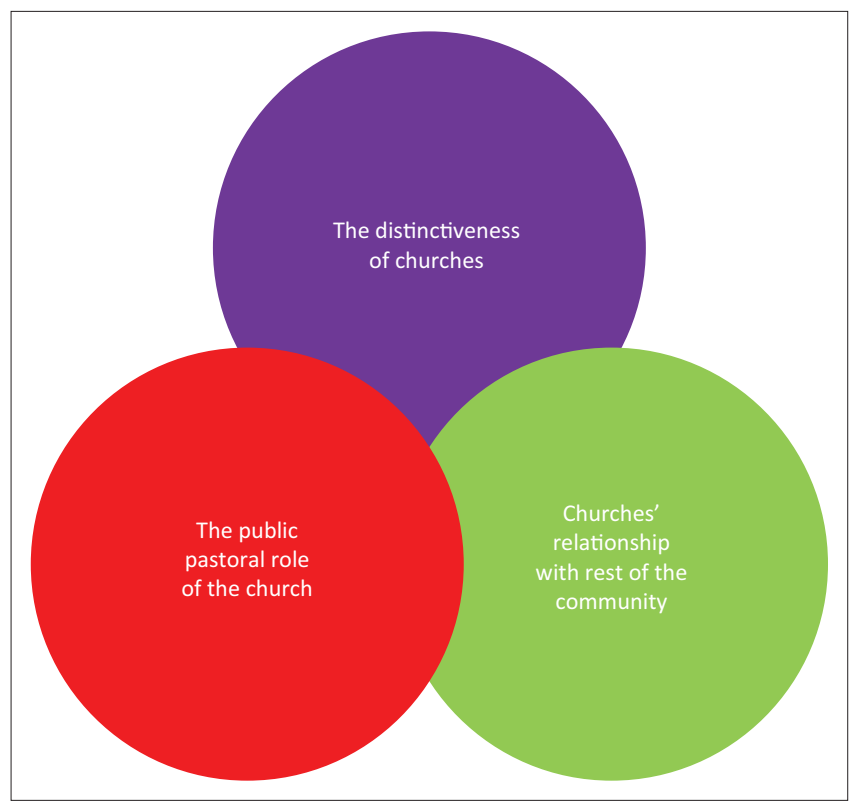

Source: Author's own work

FIGURE 1: Three interlocking areas that inform churches or congregations in public pastoral issues. ethical framework that may have to be respected. Fourthly, community congregational interventions may be weakened by the multiplicity of tasks to be performed by churches whereby spiritual tasks tend to be prioritised. The rationale for prioritising spiritually is that congregations view themselves as the custodians responsible for advancing and maintaining spiritual nourishment, while other tasks, such as public health, are performed by other institutions.

In arguing for the distinctiveness of churches, Paeth (2005) notes that Moltmann described churches as a contrast society. The distinction of the church as a contrast society entails what Lohfink (1984) also called a counter society. The church is a contrast society to the contradictions of modern society. The church as a contrast society embodies the kingdom of God. Paeth (2005) added that in advocating for a contrast society, Moltmann does not wholly affirm all of society and its ethos nor encourage the church to retreat to be an enclave. This implies that the church community as part of society lives in a real world where there are challenges in life but at the same time in anticipation of the world as it is coming to be (now and not yet). Despite this useful statement by Moltmann, he does not deal adequately with the complex relationships that churches face in society (Paeth 2005). Nonetheless, he guides us that the church is a community that exists in the world with the kingdom of God as its destination. From the scriptures the people of God are presented as a contrast society to the national structures 'in the world, but not of the world' (Jn 17:16). Hence the church community should be distinguishable (separate) (Dt 7:6-8).

The second aspect to be noted regarding church-community or society integration is that it is imperative for churches to be aware of the inherent obligation to connect with communities. This avoids churches to be exclusive community enclaves that do not relate to society, as discouraged by Moltmann. This challenges churches to forge relationships and linkages with the rest of the community. Therefore, notwithstanding the distinctiveness of churches, Vorster (2015) discerned a useful church-community or society link. He rightly connected the notion of the kingdom of God to practical church action in society. He advised that:

T]he biblical concept of the kingdom of God offers a feasible theological paradigm for constructive civil action by churches and Christians as part of civil society. This paradigm enables Christians and churches to partake as transmitters of the morality of the reign of Christ into society. Such action can be constructive by enhancing the moral directives of the reign of Christ. (Vorster 2015:7)

The third aspect to note is that the distinctiveness of churches as separate communities and the expectation to forge relationships with communities pose a challenge to church pastoral ministries to take up a public role. As already discussed, this entails bringing public wholeness (Ashby 2004), which Louw (2014) refers to as life care. This is about ensuring that pastoral and congregational ministries respond to key social issues (Miller-McLemore 2005). 
Thus the three interlocking areas that inform churches or congregations in public pastoral issues, maintaining churches' sacredness, the challenge to forge meaningful relationships with the rest of the community and the reality of the need for responsiveness to community issues (public pastoral care), indicate a church-community or society integration space that should be observed. These dimensions define both the challenge and opportunities for church community ministries.

\section{Basic diagnostic and hermeneutical model for congregational positioning and shift to AYSRH ministry as life care}

A model helps in providing a guiding framework. It highlights the connections and processes in real-life. It helps simplify complex phenomena in order to make analysis possible. In our case, a congregational diagnostic model seeks to understand and characterise the two possible defective attitudes and responsive positions that congregations may be located regarding their church ministries on AYSRH. Defective refers to ineffective ecclesiological approaches. A third dimension is proposed as a constructive approach for effective AYSRH responses. The proposed diagnostic model is concerned with understanding situations in order to develop relevant responsive congregational ministries, which Bergson (2015) called an operative ecclesiology. Louw (2016) added that an operative ecclesiology refers to performative actions of being the church within concrete contexts. It reflects on ecclesial matters not merely from the viewpoint of denominational traditions and dogmatic confessions, but within communal life systems. Thus an operative ecclesiology entails ensuring that churches and congregations become responsive to their situations, which in our case is AYSRH.

Explaining diagnosis within church and pastoral ministry, Louw (1998, 2016) explained that diagnosis is not about classification as in many medical, psychiatric and psychological models. A pastoral diagnosis is about a hermeneutical understanding of how existential life issues are linked and interconnected so that one can understand life better. The development of a diagnostic chart is based on the presupposition that the insight into the systemic networking of attitudes and paradigms helps individuals to consider different strategic options, especially when one has to connect the options to basic theological categories. Louw (2016) rightly maintained that when one sees the bigger picture, as presented in a diagnostic chart, it brings about a kind of soberness and realism. It also opens up options which create new avenues of living. Thus a diagnostic chart helps one to see the bigger picture. A big picture refers to the dynamics of life as an existential and qualitative category. Within this framework, life is a web where the dynamics and structural interplay between various situations, experiences and relationships should be understood as part of a reality.

Therefore, people and congregations should be assisted to understand the positions and attitudes that they operate from in order to facilitate possible shifts. The reality and consciousness triggered by diagnostic positions and locations challenge people to reconsider their engagements with life issues, which create new avenues for living as Louw (2016) noted. A basic diagnostic and hermeneutical model for congregational positioning and shift to AYSRH ministry as possible life care is shown in Figure 2.

Within this diagnostic model, a Balloon Christianity indicates a congregation whose response to AYSRH is akin to a balloon that could easily be popped. The congregational position is unrealistic and blind to the realities resulting 'in being in a balloon bubble position'. Youth sexual discussions are over-moralised to the extent of denialism of high HIV and pregnancy in the country and community. Rather than viewing Christian people and youth in terms of a tension and co-mingling of good and bad 'i.e. tension of Kingdom now and Kingdom not yet', the congregation holds idealistic values that are contrary to the prevailing realities. Being idealistic refers to being unrealistic by maintaining a position that youth are perfect and abstaining from sexual involvement, which is contrary to scientific evidence (Malan 2014:1). Cloete (2012:1) in her essay Youth culture, media and sexuality observed that the reality of youth sexual involvement influenced by the media among other things begs responsive church responses. She rightly argued that sex and sexuality should be theological issues that should be tackled head on by churches. Orapeleng's (2002:2) study of Seventh-Day Adventist youth revealed that $78 \%$ of the youth had been involved in premarital sex with the highest number being within the 14-18 age group. In response to the situation he recommends an integrated model that includes the family, church, school and individual. By ignoring the vivid reality of youth sexual involvement congregational leaders practise 'in the sky Christianity'. Such congregations hold an overrated view of adolescent and youth sexual resistance capacity in the context of pervasive sexual exposure, which is a defective anthropology.

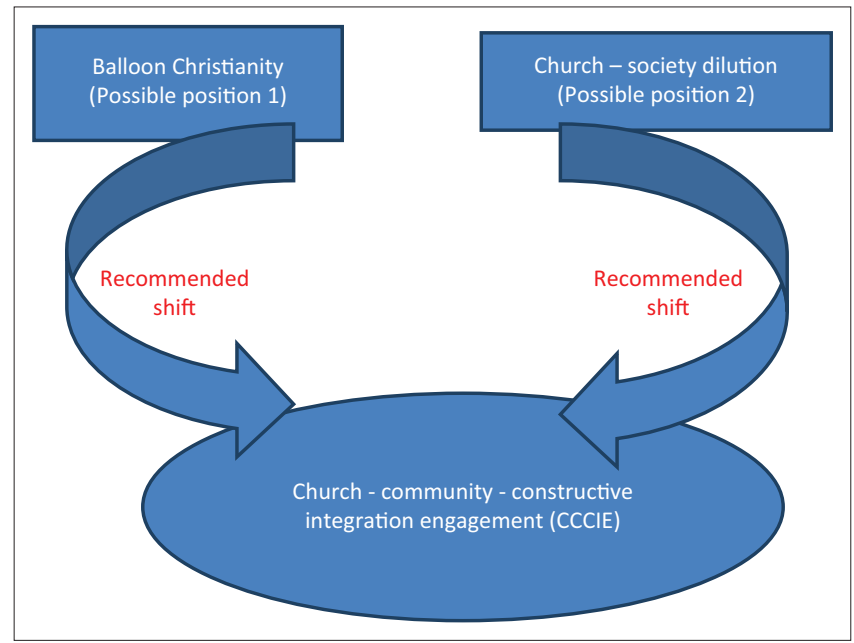

Source: Author's own work

FIGURE 2: A diagnostic and hermeneutical chart for congregational positioning and shift for AYSRH ministry. 
These congregations' engagement with AYSRH issues is characterised by idealistic and unrealistic youth sexual values by overlooking the contextual realities. Youth ministry programmes are characterised by dos and don'ts with little engagement with the context. Youth sexual involvement is viewed in terms of an offence with little or no space for sexual confession and restoration. As a result, such congregations tend to be judgemental, exclusivist and disengaged with real-life issues. Church people and youth feel caged. Church therefore is not a space of engagement with life. Little engagement occurs between the church or congregations and the rest of community structures and people. Hyunok (2013) put the issue of poor church and community youth sexuality interventions in context. Hyunok (2013:i) in his study on Youth Ministry in South Africa noted that church leaders and teachers need enough information about the youth and must be aware of the youth's developmental needs. Christian education should connect the generations. Importantly, there is a need to respond to the youth's crucial questions and issues of today. Then the youth can find what God intends them to become. Weber (2015:1) indirectly accounts for the state of poor youth ministry in South Africa by lamenting the poor research in the country. He stated that research on youth ministry in Africa and specifically South Africa tends to be influenced from studies done in the West and less in South Africa. This arises from the state of weak research on youth ministry. This gap therefore tends to perpetuate unrealistic balloon mentality regarding youth sexual issues.

An example of the position held by churches falling within this diagnostic model of a balloon includes for instance an emphasis of no sex before marriage to ensure sexual purity among youths. While this is ideal, it is unpractical and contrary to prevailing realities, which can be equated to some form of zombie ministry categories (Reader 2008). Reader (2008:1) described zombie ministry categories as frameworks of understanding that have served the church for many years and continue to shape the way people view and interpret life, when in fact such categories are increasingly becoming irrelevant. To deny that adolescents and youth are sexually active is dangerous and unhelpful denialism. Rather than being caught up in denialism, church leaders should explore ways of doing ministry that responds and addresses AYSRH issues. Hyunok's (2013:i) advice is apt that church leaders and teachers should connect older and young generations as well as respond to the youth's crucial questions and issues of today. In this case, the task of practical theology is to seek action and interventions that change the situation. Louw (2008:19) referred to this task of practical theology as fides quaerens actum (faith-seeking action, transformation and growth). This indicates that theology is ceased with the task of exploring and imagining contextually responsive ministry paradigms within the current youth programmes (i.e. operative ecclesiology). This also entails fides quaerens verbum (faith-seeking language, and words and communication messages) (Louw 2008:19) - that provides avenues for healing of AYSRH situation.
While balloon congregations' weaknesses are contextual irrelevancy and disengagement with real-life challenges, the opposite is church and society dilution. The congregations in this category hold a strong view of congregational involvement in social issues such as AYSRH. Owing to this conviction, the congregation over-commits to community issues and downplays the role of the church as a separate institution in the community, which Moltmann called contrast community (Paeth 2005). In doing so, the church and community are indistinguishable, i.e. unclear distinction in values and framework between churches and other community structures. This approach is close to what Crabb (1979:35) called 'tossed salad' in Bible and psychology integration during counselling. In the tossed salad approach, a Christian counsellor employs psychology and the Bible during counselling like someone throwing different ingredients in a salad bowl and then mix for a salad mixture. The problem with the tossed salad as Crabb (1979:35-37) argues is that it uncritically accepts, embraces and incorporates psychological notions without an understanding of the conflicting worldviews from which psychology operates. This results in some unbiblical ideas creeping into Christian counselling. Louw (1998) warns against this danger, which he calls 'complementarism'.

In this congregational approach to community challenges, church and community/society are undifferentiated in their role, premise, vision and operational framework. The focus is on kingdom now with little emphasis on the kingdom not yet. The kingdom now is a goal to be pursued vigorously without balancing the now and not yet. There is overemphasis of one side of church's mission, namely addressing of practical contextual challenges while downplaying the spiritual dimension. This approach is too human centred with little spiritual discernment of God. This human emphasis downplays the churches' practical theological and congregational missional approach (Hendriks 2007:102-104).

This approach tends to focus on youth sexuality issues from a human rights perspective (i.e. AYSRH rights) and ignores religious value formation. In doing so, youth sexual rights and issues are sometimes misconstrued as permissive. Such youth programmes weakly enforce values and responsibility. Youth sexuality discussions tend to be skewed towards biomedical sexual reproduction products such as pregnancy prevention products like injectable and condoms while downplaying faith and religious value formation. This results in a thin and unclear line between accepting the reality of youth sexual activeness for the purposes of informed ministry development purposes and youth sexual tolerance as well as permissiveness. This perception causes apathy and despondence on parents and guardians, which results in them distancing themselves and withdrawing their children due to feeling a sense of moral betrayal by churches. Thus the conflation of Christian and secular values with little or no clear influence and position based on Christian values on youth sexual issues results in a backlash from parents and worse it weakens the critical contribution of churches as religious communities to youth sexuality matters. 
This approach is clearly dispelled by Klepp, Flisher and Kaaya (2008:7) who advised that factors that facilitate or hinder sexual and reproductive health issues that should be attended to are wide. The issues include complex personal, social, structural and environmental factors that interplay and influence each other. And communities and churches are some of the structures and spaces whose contribution needs to be understood.

Thus, church and society dilution congregational approach diminishes the contribution of churches in youth sexual matters from a value formation perspective. In doing so, the foundational Christian values are undermined yet the core contribution of churches in character and value formation is well acknowledged and documented. The positive contribution of churches to youth sexual issues was revealed from Frank et al.'s (2008) study that reported that, among other things, sexual culture and gender roles among youth are rooted in religious belief systems. For instance, African traditional religious groups were twice as likely, relative to Christian religious groups, to engage in sexual activity. For young Zulu men, early fatherhood was an affirmation of masculinity and strength. In the light of these findings the researchers recommended that religious groups should take a more aggressive role in youth sexual matters. A similar positive role of churches in youth sexual issues was revealed in Zambia where the study revealed that religious affiliation resulted in delayed sexual initiation (Agha et al. 2006). Therefore, it is important to maintain a strong Christian approach particularly value formation in church youth sexuality programmes. An AYSRH rights should be balanced with a clear Christian message on values and responsibility. Ngokwana's (2013:iv) advice based on his study on the role of churches in HIV prevention among young adults in Limpopo province that churches should teach young people holistically about HIV and sexuality issues is important. $\mathrm{He}$ maintains that holistic AYSRH life skills should form the agenda for church youth ministries.

The criticism of contextual irrelevancy and disengagement with real-life challenges raised against balloon congregations and the downplaying of distinctive Christian sexuality value and character formation resulting in church youth ministries dominated by youth sexual reproductive health rights perspective pose a challenge to churches in developing a church AYSRH model that is distinctively Christian but fully responsive to the prevailing community youth sexuality challenges. Such a model should uphold the sacredness of the church community while observing the public role of the church as a community institution. To that end, a ChurchCommunity, Constructive, Integration and Engagement (CCCIE), which will be called CCCIE (hereafter) is proposed. As advised by Hyunok (2013:i), the approach strives to ensure that church leaders and teachers are informed and guided by information about the youth, their developmental needs and the prevailing context. It strives to respond to the youth's crucial AYSRH questions and issues of today as they arise among young Christians.
The CCCIE congregational AYSRH approach is based on a premise that contextual youth sexuality issues should be located within a Christian value framework that is balanced with responsible sexual reproductive health rights. This approach views Christian youth sexual values and rights as allies that should be exercised responsibly. In maintaining this dual and integrated role, the church upholds its religious role, framework and values as informed from the Bible but at the same time, recognising that the church has a public community role that may extend beyond spiritual matters. The public societal duty of the church may be done without accompaniment with a religious message but underlined by an ethic of general care and love (agape) for humanity. By maintaining the sacred role of the churches and the humanistic foundations of sexual rights perspectives in AYSRH programmes, the CCCIE acknowledges a permanent tension between church Christian values and society's humanistic values. This tension arises from the churches' dilemma that on the one hand they have to uphold biblical teaching and moral values of sexual abstinence until marriage while at the same time responding to the reality of youth who are sexually active. The tension of biblical values and societal realities is well acknowledged in practical theology. Heitink (1999) and Louw (1998) referred to the tension between revelation (the Bible) and experience (social realties) as a health and normal bipolarity. Thus, with the church being a subsystem of society (Magezi 2012), this approach aims to overcome superficial youth sexual discussions and programmes that scratch on the surface. It attempts to do so by focusing on legitimately Christian-rooted values that are juxtaposed with social realities.

Moltmann's notion of churches as a contrast society (Paeth 2005) and Lohfink's (1984) idea of the churches as counter society indicate that indeed a distinction between churches as a sacred community from society should be respected. This implies that contextual realities should be considered and located within a Christian framework, which entails health integration of God's mission and human contexts (Louw 1998). There has to be a balanced view of humanity spiritual struggle, namely ideal values versus contextual realities. The kingdom now and not yet should be viewed as coexisting complex realities. This means youth sexuality issues should be located within Christian value framework whereby rights are balanced with Christian values and responsibility. Viewed this way, youth sexual health ministry should incorporate a preventive dimension as well as empowerment with life skills. Youth sexual programmes should maintain clarity of both public health message and Christian Bible message and adopt a constructive way of integrating the messages.

AYSRH programmes should empower youth from a clear Christian value framework and highlight the spiritual and practical public health benefits of such values. This means that youth ministries should be characterised by a constant negotiation and critical reflection on what it means to be a Christian youth living in a country or community where the 
majority are being sexually involved. In doing so, youth ministry serves the now and not yet dimensions of youth sexuality within the Christian value framework. There has to be co-existence of exclusion and inclusion, meaning general acceptance among youth groupings of those who have been sexually involved (inclusion) but emphasising spiritual values that are exclusive Christian values. To ensure that AYSRH activities do not become an additional burden, the interventions should be incorporated in the existing youth programmes. The focus should include AYSRH value formation and prevention skills from Christian value perspective, for instance discouragement of fornication, which has clear reproductive benefits, while at the same time public health messages of pregnancy control and safe sex are placed within a responsible personal management. Such programmes could be integrated in church youth curricula and activities.

AYSRH programmes should be implemented systemically across church programmes: women groups, men's groups and youth groups. The need for systemic AYSRH programmes was noted by Frank et al.'s (2008) study that revealed that there is generally poor parental communication around sex and sexual reproductive health (SRH) in South Africa. The study noted that despite the parents viewing the media as promoting sexual activity among teenagers, parents remain silent. Therefore, family and parenting programmes should be strengthened among families. Programmes such as effective parenting, home management, Christian family life, family communication and others could be used to improve parental communication on AYSRH matters. The family programmes should be complemented by church and community engagement where churches could conduct integrated sexual reproductive activities such as church clubs, local school clubs and advocacy for youth-friendly AYSRH services in community health facilities.

\section{Conclusion}

This article highlights an alarmingly high rate of HIV and general, poor-level sexual reproductive health among adolescents and youth. Parents who are unaware of their children's sexual experiences worsen this situation. Within this context a call has been made by various bodies including the National Adolescent Sexual and Reproductive Health and Rights Framework Strategy (2014-2019) to include a strong community and faith-based responses. In response to this call, churches have been identified as strong contributors to positive adolescents and youth sexual health response. A CCCIE approach that upholds biblical teaching but at the same time taking a strong social contextual response to AYSRH has been proposed. The approach juxtaposes the church and its distinctive values and at the same time practically responding to realities of the needs of adolescents and youth in the communities. In so doing, the approach upholds the sacredness of the church while observing the public role of the church as a community institution that is responsive to community needs.

\section{Acknowledgements Competing interests}

The author declares that he has no financial or personal relationships which may have inappropriately influenced him in writing this article.

\section{References}

Agha, S., Hutchinson, P. \& Kusanthan, T., 2006, 'The effects of religious affiliation on sexual initiation and condom use in Zambia', Journal of Adolescent Health 38, 550-555. http://dx.doi.org/10.1016/j.jadohealth.2005.04.012

Ashby, H.U., 2004, 'Accountability', Journal of Pastoral Theology 14(2), 4-12.

Babbel, B.E.,, 2012, 'Evaluating equity in the provision of primary health care in Tanzania', Master of Public Policy Degree, Oregon State University, viewed 10 June 2016, from https://ir.library.oregonstate.edu/xmlui/.../Babbel_MPPEssay.docx?

Beksinska, M.E., Pillay, L., Milford, C. \& Jennifer, S.A., 2014, 'The sexual and reproductive health needs of youth in South Africa - History in context', South African Medical Journal 104(10), 676-678. http://dx.doi.org/10.7196/SAMJ.8809

Bergson, E., 2015, Catholicity challenging ethnicity. An ecclesiological study of Churches in post-apartheid South Africa, Uppsala University, Uppsala.

Bezuidenhout, R. \& Naudé, P., 2002, 'Some thoughts on "public theology" and its relevance for the South African context', Scriptura 79, 3-13.

Cloete, A., 2012, 'Youth culture, media and sexuality: What could faith communities contribute?', HTS Teologiese Studies/Theological Studies 68(2), Art. \#1118, 1-6.

Crabb, L.J., 1979, Effective Biblical counselling, Grand Rapids, MI.

Dambisya, Y.M. \& Ichoku, H.E., 2012, 'African triage: Assessing alternatives to health care privatisation south of the Sahara', in D. McDonald \& G. Ruiters (eds.) Alternatives to privatization public options for essential services in the global South, Routledge, New York.

Flanagan, B. \& Thornton, S. (eds.), 2014, The Bloomsbury guide to pastoral care, Bloomsbury Publishing, London.

Forster, D.A., 2015, 'What hope is there for South Africa? A public theological reflection on the role of the church as a bearer of hope for the future', HTS Teologiese Studies/Theological Studies 71(1), Art. \#2814, 1-13. http://dx.doi. org/10.4102/hts.v71i3.2814

Foster, G., 2010, 'Faith untapped: Linking community-level and sectoral health and HIV/AIDS responses', in The United States President's emergency plan for AIDS relief, viewed 28 July 2016, from http://www.pepfar.gov/documents/ organization/195614.pdf

Frank, S., Esterhuizen, T., Jinabhai, C.C., Sullivan, K. \& Taylor, M., 2008, 'Risky sexual behaviours of high-school pupils in an era of HIV and AIDS', South Africa Medical Journal 98, 394-398.

Graham, E. \& Rowlands, A. (eds.), 2005, Pathways to the public square: Practical theology in an age of pluralism, Transaction Publishers, London.

Green, A., Shaw, J., Dimmock, F. \& Conn, C., 2002, 'A shared mission? Changing relationships between government and church health services in Africa', International Journal of Health Planning and Management 17, 333-353. http:// dx.doi.org/10.1002/hpm.685

Gribble, J. \& Bremner, J., 2012, The challenge of attaining the demographic dividend, population reference bureau, policy brief, viewed September 2015, from http:// www.prb.org/pdf12/demographic-dividend.pdf

Heitink, G., 1999, Practical theology: History, theory, action domains, Grand Rapids, MI.

Hendriks, J.H., 2007, 'Missional theology and social development', HTS Teologiese Studies/Theological Studies 63(3), 999-1016.

HSRC, n.d., Youth and the demographic dividend, viewed 15 July 2016, from http:// www.hsrc.ac.za/uploads/pageContent/1289/Lead\%20Speaker\%20Dr\%20 Inonge $\% 20$ Kamungoma $\% 20$ Dada $\% 20$ UNFPA $\% 20$ Country $\% 200$ ffice.pdf

Hyunok, Y.I., 2013, 'Youth ministry and leadership in the world evangelical mission international (South Africa): An inclusive ministry approach', MA dissertation (Practical Theology), University of Pretoria.

Juma, F., 2015, 'Public theology in the face of pain and suffering: A proletarian perspective', Consensus 36(2), 1-14, viewed 10 July 2015, from http://scholars. wlu.ca/consensus/vol36/iss $2 / 6$

Klepp, K., Flisher, A.J. \& Kaaya, S.F. (eds.), 2008, 'Introduction', in K. Klepp, A.J. Flisher \& S.F. Kaaya (eds.), Promoting adolescent sexual and reproductive health in East and Southern Africa, pp. 7-11, HSRC Press, Cape Town.

Koopman, N., 2009, 'For God so loved the world ... some contours for public theology in South Africa', Dutch Reformed Theological Journal 50(3\&4), 409-426.

Koopman, N., 2014, 'Bonhoeffer and the future of public theology in South Africa. The on-going quest for life together', NGTT DEEL 55(suppl. 1), 985-998.

Lawler, M., 2015, 'Adolescent focused HIV care in South Africa', viewed 2 July 2016 from http://www.sahivsoc.org/upload/documents/Adolescent $\% 20$ focused $\% 20$ HIV\%20care\%20in\%20South\%20Africa.pdf

Lebese, R.T., Maputle, S.M., Ramathuba, D.U. \& Khoza, L.B., 2013, 'Factors influencing the uptake of contraception services by Vatsonga adolescents in rural communities the uptake of contraception services by Vatsonga adolescents in rural communities of Vhembe District in Limpopo Province, South Africa', Health
18(1), Art. \#654, 1-6. http://dx.doi.org/10.4102/hsag.v18i1.654 
Lohfink, G., 1984, Jesus and community, transl. J. Galvin, Fortress Press, Philadelphia, PA.

Louw, D.J., 1998, A pastoral hermeneutics of care and encounter, Lux Verbi, Cape Town.

Louw, D.J., 2008, Cura vitae: Illness and the healing of life in pastoral care and counselling, Lux Verbi, Cape Town.

Louw, D.J., 2014, Wholeness in hope care on nurturing the beauty of the human soul in spiritual healing, LIT, Wien.

Louw, D.J., 2016, Between xenophobia and xenodochia in an operative ecclesiology of home: The plight of refugees and migrants as challenge to a diagnostic approach in a pastoral hermeneutics of caregiving, Unpublished paper.

Magezi, V., 2007, HIV and AIDS, poverty and pastoral care and counselling: A homebased and congregational systems ministerial approach in Africa, Sun Media, Stellenbosch.

Magezi, V., 2012, 'From periphery to the centre: Towards repositioning churches for meaningful contribution to public health care', HTS Teologiese Studies/ Theological Studies 68(2), Art. \#1312, 1-8. http://dx.doi.org/10.4102/hts. v68i2.1312

Malan, M., 2014, 'SA has highest number of new HIV infections worldwide - Survey', viewed 20 June 2016, from http://bhekisisa.org/article/2014-04-01-sa-holdshighest-number-of-new-hiv-infections-worldwide-survey

Mati, J.M., 2013, 'Bringing back "faith" in discourses of African civil society: Views from a convening in Nairobi', ISTR Africa Network Regional Conference, Nairobi, July 11-13, 2013.

McClure, B.J., 2010, Moving beyond individualism in pastoral care and counselling Reflections on theory, theology and practice, Cascade Books, Oregon.

Miller-McLemore, B.J., 2005, 'Pastoral theology and public theology', in E. Graham \& A. Rowlands (eds.), Pathways to the public square, pp. 95-106, Transaction Publishers, London.

National Adolescent Sexual and Reproductive Health and Rights Framework Strategy (2014-2019), South Africa, Ministry of Social Development, South Africa.

Ngokwana, M.P.C., 2013, 'The role of churches in HIV prevention among young adults in Polokwane municipality, Limpopo province', Master of Arts dissertation, UNISA.

Orapeleng, G.M., 2002, 'Pre-marital sex among youth in Seventh Day Adventist in Botswana and possibilities for preventive action', Master of Theology dissertation UNISA.

Paeth, S.R., 2005, 'Jürgen Moltmann's public theology', Political Theology 6(2), 215-234. http://dx.doi.org/10.1558/poth.6.2.215.65446

Ramsay, N.J. (ed.), 2004, Pastoral care and counseling: Redefining the paradigms, Abingdon Press, New York.

Reader, J., 2008, Reconstructing practical theology: The impact of globalization, Ashgate, Aldershot.
Restless Development, 2015, Baseline situation analysis for the development of a model for effective implementation of integrated school health programme at the Nzululwazi High School and surrounding community report, viewed 10 July 2016, from http:// restlessdevelopment.org/file/school-health-programme-baseline-report-pdf

SA Census, 2011, 2011 Census, viewed 1 June 2016, from http://www.statssa.gov. za/?page_id $=3839$

Samuels, F., Geibel, R. \& Perry, F., 2010, 'Collaboration between faith-based communities and humanitarian actors when responding to HIV in emergencies', project briefing no 41, Overseas Development Institute, viewed 1 August 2016, from https://www. odi.org/publications/4821-hiv-aids-religious-groups-emergencies

Save the Children and UNFPA, 2009, Adolescent sexual and reproductive health toolkit for humanitarian settings: A companion to the inter-agency field manual on reproductive health in humanitarian settings, viewed 12 October 2016, from http://www.unfpa.org/publications/adolescent-sexual-and-reproductive-healthtoolkit-humanitarian-settings

Statistics South Africa, 2015, Statistical release - Mid-year population estimates 2015 viewed 3 July 2016, from https://www.statssa.gov.za/publications/P0302/ P03022015.pdf

Statistics South Africa, 2013, Statistical release - General household survey 2013, viewed 5 July 2016, from http://www.statssa.gov.za/publications/P0318/P03182013.pdf

Strachan, O. \& Vanhoozer, K., 2015, The pastor as public theologian: Reclaiming a lost vision, Baker Academic, Grand Rapids, MI.

Swart, I. \& De Beer, S., 2014, 'Doing urban public theology in South Africa: Introducing a new agenda', HTS Teologiese Studies/Theological Studies 70(3), 1-14.

UNESCO, 2013, Young people today time to act now, UNESCO.

UNFPA, 2016, Young people - Fact sheet, viewed 20 June 2016, from http:// countryoffice.unfpa.org/filemanager/files/southafrica/young_people march_2013_fact_sheet.pdf

UNFPA, 2014, 'UNFPA South Africa - Sexual and reproductive health', viewed 20 June 2016, from http://countryoffice.unfpa.org/southafrica/2011/11/24/4255/ reproductive_health_and_hiv/

University of Pretoria, n.d., Centre for Public Theology viewed 1 June 2016, from http://www.universityofpretoria.co.za/centre-for-public-theology

Vorster, J., 2015, 'Kingdom, church and civil society: A theological paradigm for civil action', HTS Teologiese Studies/Theological Studies 71(3), Art. \#2816, 1-7. http:// dx.doi.org/10.4102/hts.v71i3.2816

Weber, S., 2015, 'A (South) African voice on youth ministry research: Powerful or powerless?', HTS Teologiese Studies/Theological Studies 71(2), Art. \#2973, 1-6.

World Council of Churches, 2010, 'Health system strengthening: Focus on Church based pharmaceutical human resources', Contact Magazine no 189, JanuaryMarch 2010, A publication of the World Council of Churches, viewed 1 July 2016 from http://wcc-coe.org/wcc/news/contact.html

Zvobgo, C.J., 1986, 'Medical missions: A neglected theme in Zimbabwe history, 1893-1897', Zambezia Xiii(ii), 109-118. 